\title{
麻痺手の母指対立運動再建の経験
}

$\begin{array}{ccccc}\text { 熊本大学医学部整形外科学教室 } & \text { 水 } & \text { 岡 } & \text { 二 } & \text { 郎 } \\ & \text { 堀 } & \text { 尾 } & \text { 慎 } & \text { 弥 } \\ & \text { 山 } & \text { 田 } & \text { 文 } & \text { 夫 }\end{array}$

\section{The Experience of the Restoration of Opposition for the Thumb in Paralytic Hand.}

by

\author{
J. Mizuoka, S. Horio \& F. Yamada \\ Department of Orthopedic Surgery, \\ Kumamoto University School of Medicine.
} (Direct.: Prof. T. Tamai)

母指の intrinsic muscle が麻疩している手の機能 再建には，母指の pulp と他の指の pulp とを向い合 わせ, pulp to pulp pinch 之強い grip が出来るよ うにする必要がある.

母指を他指と対向位にするには，母指を外転し手掌 面にほડ゙垂直な面まで移動させ，母指と示指の中手骨 のなす角度を $45^{\circ}$ となし，母指を少しく回内位に固定 しなければならない。

われわれは過去に小児麻痺 2 例, 手の外傷 1 例, 㮌 41 例, 計 44 症例について母指対立運動再建術を施行 し, こ〉に再建術について述べる.

intrinsic muscle の機能は非常に複雑で, 対立運 動の不能及び变形発生の原因並びに状態を知つて少く と屯最む大切な対立運動の再建を行うために, 腱移向 術を試みることになる。

従来, この手術には種々の方法が試みられ, 動力筋 としては 11 の筋が利用されているが，大別してみる と, 腕関節の屈筋及び伸筋を利用するもの, sublimis を利用する方法がある. しかし前者では遊離腱移植が 必要であり, 更に 2 ケ所で縫合する必要があるため移 向経過が長く瘾着を起し易いので, 対立の力が弱い. われわれは初期の 11 症例に於いて, palmaris longus を動力筋とし, Os pisiformis 飞 pulley を作り, extensor pollicis brevis の筋腱移行部で切断しその 附着部に引き出し, 更に皮下を通し, pulley 通過後 palmaris longus に縫合したが好成績を得なかつた。 即ち上記の理由の他に，滑車部の近くに縫合部が来る
こと, 瀬では屡々 extensor pollicis brevis が麻瘒 していることより術後の経過と共に 対立運動は減弱 した.

一般に sublimis の移向では筋力が強く, excursion が広く, 縫合部が母指の附着部のみにあるととにより 最むよい成績を招さめる. 動力筋としての sublimis は環指のものが最む多く利用されるが, 癩に於いて は, 高位の尺骨神経麻㾝のため, M. flexor carpi ulnaris と尺側の M. flexor digitorum profunda の 麻㾝が屢々認められるので, てのような症例では, 中 指の sublimis を利用するか, 或いは遊離腱移植によ る方法が施行される.

良好な対立運動を得るについて, Bunnell は移向腱 の走向を母指の内旋を与えるために基節基部尺側よ り，M. P. 関節の直上を通し，それより手掌の皮下を 通して, 豆骨部の滑車に向わねばならないと述べ, Littler, Riordan, Flynn は, Duchenne の生理解剖 学的見地から述べている処の, pinch と grip に対し ては, M. abductor pollicis brevis が母指球筋中最 あ重要であると云う意見儧成して， sublimis を $M$. abductor pollicis brevis の走向に一一致させ, 豆骨部 より基節基部橈側に移向している.

術後の成績を見ると, 移向腱が母指球の皮下を通過 する走向が橈側にずれた時は, 母指の外転は減弱して いる. 即ち, pulley の機能を失つた時, 腕関節の横雖 璧のレベルで, 移向腱が palmaris longus より橈側 にずれた場合等である. 
Thompson 変法は外転力が弱い，その原因はその 走向のために内転筋の様な作用機序を呈し，真の対立 運動は得られないためである.との事からわれわれは M. abductor pollicis brevis の走向に可及的に一致 させるために, transverse carpal ligament の遠位 縁を近位方向に一部裂いて pulley とした一例を経験 しているが，現在の処良好な成績を得ている。

M. flexor carpi ulnaris の麻㾝のない場合は, Goldner, Irwin の云う dynamic pulley technic が 利用される.この pulley は移向腱が近位橈側にずれ る傾向があるが，癒着の恐れはない，乙の橈側偏位を 防止するため， pulley の近位部を尺骨の骨膜に縫合 するが，乙の際腕関節を背屈位になし断裂を防止する が, 遊離腱移植により, flexor carpi ulnaris と尺骨 に架橋する. 又 Irwin は extensor carpi ulnarisに loop しており, flexor carpi ulnaris の增強のため palmaris longus をむつて補強する方法も考えら れる.

Riordan は flexor carpi ulnaris の麻㾝のあるも のでは，確実に豆骨部に pulley を作る必要があるた めに, static pulley technic を採用した. この作製 法は図に示す如き方法が考えられる，しかし，腱の一 半で pulley を作る方法では癒着のおそれと, 術後 pulley が延長して移向腱の橈側偏位及び pulley の断 裂が認められた症例がある. 又 M. flexor carpi ulnaris の腱を切断し，その末梢部を利用して pulley を作る方法があるが, 本法では腕関節の橈屈を起す恐 れがあるので，これを防ぐため，palmaris longusを 豆骨に移向する方法もある.

移向腱の附着法については多くの意見がある処であ るが, Bunnell は母指の内旋を得るために基節尺・背 侧部に附着点をおいている。

われわれは，図の如き種々の方法を利用したが，多 数例においては良好な母指の内旋は得られたが, M. P 関節の背屈と D.I.P. 関節の掌届を招来し, tip-to-tip pinch となり, 著しい例では示指の tip と末節背の pinch しか可能でなかつた例がある.母指球筋の完全 麻㾝例では M.P 関節の Stabilizer である固有屈筋が 㗢かなく，それに加えるに移向腱の变引力が M.P 関 節の背屈を行わしめる如く働くため, 及び extensor pollicis longns の圧迫と癒着によつて, M.P 関節の 過伸展と末節の届曲を生ずるものと考える.

pull-out 法は早期に運動練習が出来ない欠点があ
り，骨萎縮のある指節に二孔をあけるのは有利でな い. この附着部が基節の遠位であるか, 移向腱が M.P 関節の頂上より遠位にある時には M.P 関節は屈曲し て, D.I.P. 関節は伸展するが, pinch はむしろ示指を 除く尺側 3 指と容易になる.M.P 関節屈曲を防止する ため sublimisを extensor pollicis brevis の掌側 を通し, extensor pollicis longus の背側を通した が，かえつて背側屈曲を増強した。

強力な外転と末節を伸展する方法として, Littler (1949), Riordan (1953), Flynn (1957) は sublimis をM. abductor pollicis brevis の走行に一致させて 走らせ, Littler は筋膜に, Riordan は sublimis の 末端を extensor pollicis longus に縫合し, Flynn は該伸筋にひつかけて縫合した。われわれは母指球筋 の萎縮の軽度なものに Thompson 変法の附着法を施 行している. これらの方法で, M.P 関節の過伸展と, 末節の屈曲を防止し，良好なる pulp to pulp pinch が可能となり, 現在専らこれらの方法を用いて満足す べき結果を得ている.

尚内転拘縮のある症例では, 術前の理学的療法及び 拘縮除去の如何が術後の成績を大いに左右する.
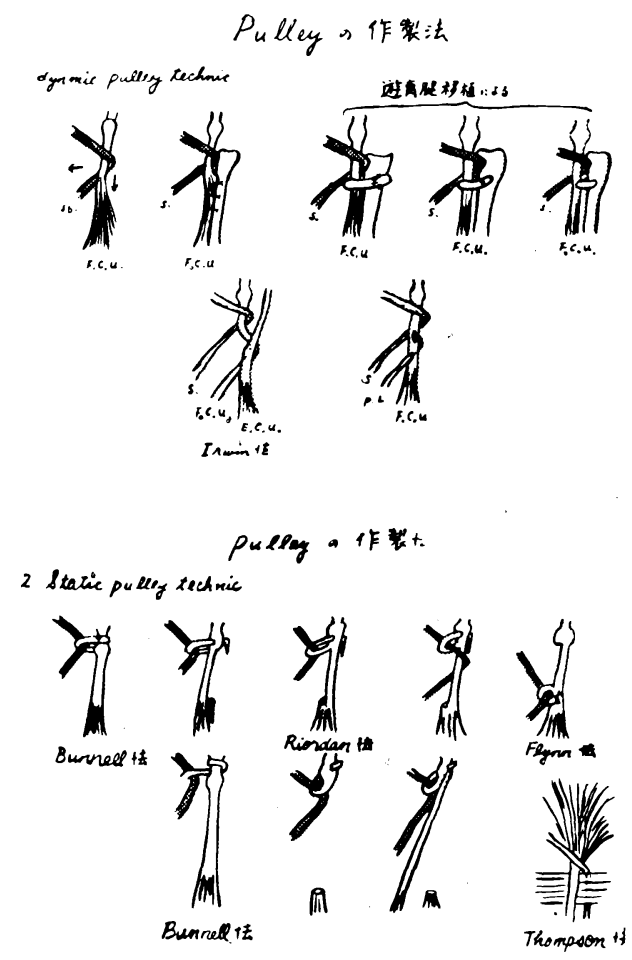


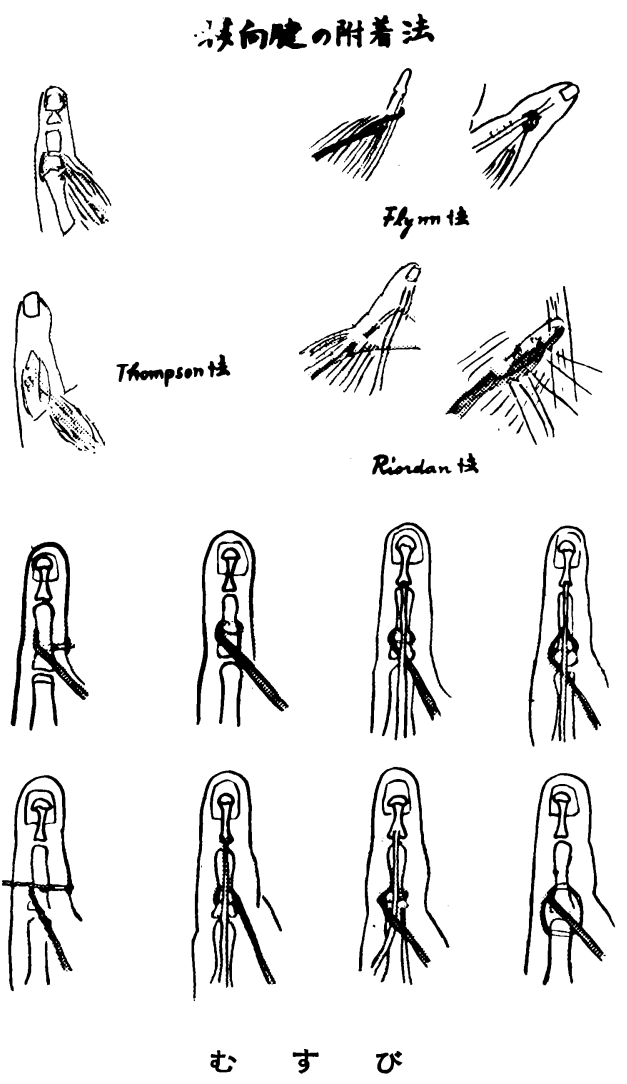

以上麻㾘手の母指対立運動再建術に於ける, 動力筋 移向腱の走向, 滑車の作製及び移向腱附着法について 検討した.

（終りに臨み御校閲, 御指導を頂いた恩師玉井教授に 深謝する.)

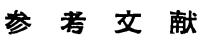

1) Ney: A Tendon Transplant for Intrinsic Hand Muscle Paralysis. Surg. Gyne. and Obst. Vol. 23, 342, (1921).

2) Steindler: Flexor Plasty of the Thumb in Thenar Palsy. Surg. Gyne. and Obst. Vol. 50, 1005, (1930).

3) Bunnell : Opposition of the Hand. J. B. J.S. Vol. 120, 269, Apr. (1938).

Surgery of the Hand. 3rd Ed. Lippincott. (1957).

4) Mayer: Operative Reconstruction of the Paralysed Upper Extremity. J.B. J.S. Vol. 21, 377, Apr. (1939).
5) Thompson: A Modified Operation for Opponens Paralysis J. B. J.S. Vol. 24, No. 3. (1942).

6) Thompson: Opposition of the Thumb and Its Restoration.. J. B. J. S. Vol. 42-A, No. 6, Sep. (1960).

7) Goldner, Irwin: An Analysis of Paralytic Thumb Deformities J. B. J. S. Vol. 32-A, No. 3, 627. (1950).

8) Littler: Tendontranofers and Arthrodesis in Combined Median and Ulnar Nerve Paralysis. J. B. T.S. Vol. 31-A, No. 2, Apr. (1949).

9) Flynn: Reconstruction of the Hand After Median-nerve Palsy New. Eng. J. M. 256. No. 15, 676 (1957).

10）津下 - 他：母指対向運動再建手術についての考 察, 形成美容外科, Vol. 3, No. 4, 262. (1960).

11) Campbell's Operative Orthopaedics 3rd Ed. Vol. 2, 1815. (1956).

12) Riordan: Surgery of the Paralytic Hand. Instructional Course Lectures, American Academy of Orthopedic Surgeons, 15; 79. (1959).

13) Brand: The Reconstruction of the Hand in Leprosy. Leprosy Review, 24 ; 104. (1953).

14）水岡：廎汇打ける手の外科, 熊本医学会雑誌, 34巻補冊 8,1651 , (1960).

\section{兵問}

\section{長崎大学整形外科 玉 置 拓 夫}

癩患者の場合, 腱移植後機能を獲得するのは脊䯣性 小児麻瘏の場合より困難な事はないか，後療法のやり 方について具体的に伺いたい。

\section{回答}

演者

䫐患者では手に知覚麻㾝がある為に術後療法は慎重 にしなければならない。

2 週後よりリゾール浴. 3 週後よりバイブラーバ ス. 6 週後より elastic splint を利用する. 最近で は泥浴等も施行している.

術後最あてわい事は体重をかけて手掌をついて倒れ る事である，術後はゴムバンドで拇指を対立位に置い ている.

算問

広島日赤病院整形外科高岸直人 次の 3 点について同いたい.

1. 何故 sublimis をとる時に縦に皮切を加える 
のか.

2. sublimisをとつた後 hyperextension 又は flexion contracture が来ないか.

3. Flynn の方法のどこが悪いか.

回答

演者

癩患者では P.I.P. 関節掌側の crease に沿つて皮軍 裂が生じ, panaritium の原因となり，横切開を加え る事は皹裂発生を助長するので crease にか〉らない 様掌側に縦切開を加え, 此れが原因で屈曲拘縮を起し た例は経験していない.

sublimis は其の附着部より切離している. 長く slip を残すと届曲拘縮を起す. Riordan の方法は術 後経過が短いのでよくわからないが, 現在の処, 良好
な結果を得ている. 堅固な固定を行う為に Thompson 変法の附着法を行つている.

追 加

熊本大学整形外科 玉 井達二 皮膚に縦切を加えたのは crease の部にはラガーデ ンを作り易いからである。

Leprosy ではラガーデンを作り易いし，少しであ 危険な道を通らないという目的でこの方法を行つて いる.

縦切によつて拘縮は起さない。

術前に練習させ，拘縮をとつて行えば，横切しても ラガーデンは生じないかも知れない.

\title{
顎 関 節突起骨折の 統計的観 察
}

\author{
九州大学医学部歯科学口腔外科学教室 中 富 憲 次 郎
(指導: 藤野 博教)
}

\section{Statistical Observation of Fractures of the Mandibular Condylar Process}

by

\section{Kenjiro Nakatomi}

Department of Dentistry and Oral Surgery, Faculty of Medicine, Kyushu University.

(Director: Prof. H. Fujino),

\section{緒言}

我々曾科口腔外科領域に於いても，顔面骨，顎骨々 折患者は，年次増加の傾向にあるが，私は昭和 25 年 4 月から, 昭和 35 年 3 月迄, 最近 10 年間の統計的観 察を試み，更に，遠隔成績に依り，二・三の知見を得 たが, 今回は比較的頻度が高く, 然も治療方法, 後遺 障碍等について，その位置的，機能的，特異性から， 問題点の多い, 顎関節突起骨折について述べる.

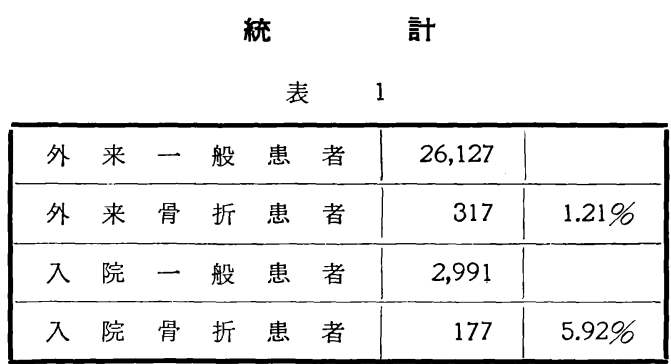

外来入院・骨折患者・年度別推移（中富, 梅崎）

\begin{tabular}{|c|c|c|c|c|c|c|c|c|c|c|c|c|c|c|}
\hline \multicolumn{2}{|c|}{ 年 } & \multicolumn{2}{|c|}{ 度 } & \multirow{2}{*}{$\frac{25}{20}$} & \multirow{2}{*}{$\frac{26}{38}$} & \multirow{2}{*}{$\frac{27}{28}$} & \multirow{2}{*}{$\frac{28}{28}$} & \multirow{2}{*}{$\frac{29}{21}$} & \multirow{2}{*}{$\frac{30}{21}$} & \multirow{2}{*}{$\frac{31}{27}$} & \multirow{2}{*}{$\frac{32}{34}$} & \multirow{2}{*}{$\frac{33}{46}$} & \multirow{2}{*}{$\frac{34}{40}$} & \multirow{2}{*}{$\frac{35}{14}$} \\
\hline 外 & 来 & 患 & 者 & & & & & & & & & & & \\
\hline 入 & 院 & 患 & 者 & 14 & 25 & 10 & 13 & 14 & 15 & 14 & 23 & 23 & 22 & 4 \\
\hline
\end{tabular}

